\title{
Reshaping the National Image of Azerbaijan through Nation Branding Endeavours
}

\author{
Sana Imran \\ Khazar University, Azerbaijan
}

\section{Introduction}

Nation branding communicates a nation's policies and culture to an international audience, the public face of international diplomacy (Jordan, 2014). History, culture, religion, language, geography, politics and national icons are the constituents of nation brand identity. Nation branding is an enormous undertaking, which cannot be left on marketers, brand managers or advertisement experts alone. Instead, afine blending of nation's culture is required for the success of nation branding campaign. Nation brands shape the strategic framework for a nation's cultural policy and are reflected through branded exports, brand ambassadors, cultural artifacts, standard of governance, achievements in sports and tourism initiative etc. Essence of nation brands is extracted from the culture, language, literature, music and architecture of intended nation. Audiences of nation brand are domestic consumers, external consumers, domestic firms, external firms, inward investors, governments and the media. Whether commercial approaches of nation brand would be well received by the government and society or not and can a nation's influence can be increased through nation branding effort emerge as two aspects that merit more attention. In the globalized world of today, nation branding has become a compulsion for nations to optimize their cultural and economic potential. If you are not making a concerted effort to brand your nation, other people might do it for you - and for their own purposes (Tim Lincoln, 2015).

Besides developed nations, the developing countries have also joined the bandwagon to gain global recognition and improve their national image through nation branding. Azerbaijan is a South Caucasian state, situated at the crossroads of Asia and Europe. This developing Muslim country is characterized with a pluralistic society and exemplary inter faith / sectarian harmony. Spirit of coexistence and multiculturalism are the trademarks of Azeri society. The country received a mixed heritage of culture from Ottoman, Russian and Persian Empires. 
Predominantly a Seljuk Turk nation, Azerbaijan has been long ruled by Russians and influenced by Iran on demographic pretexts. Azerbaijan appears to be struggling to establish its own national identity, in adjacency of mighty neighbours like Russia, Iran and Turkey. In a bid to seek global recognition, Azerbaijan has embarked upon a number of nation branding initiatives, aimed at promoting Azerbaijani identity, improving national image and enhancing economic stamina.

This study highlights that nation branding techniques that can be used to heighten national identity and improve the national image. Exploring a correlation between national identity and national image, nation branding practices will also be discussed. Azerbaijan has been selected as a preferred choice for research, due to available scope and ever growing awareness about nation branding. Rationale and contours of nation branding initiatives will be analyzed for ascertaining the efficacy of nation branding endeavours of Azerbaijan.

\section{National Identity}

National identity is the sense of belonging one has to a state or a nation, or a sense of solidarity one feels towards a particular group, disregarding one's actual citizenship status. A collective of people, united by shared cultural features, myths and values (Barrington).In the recent political philosophy, concept of national identity has been used with increased frequency, especially by the philosophers arguing for legitimacy of a principle of political self-determination (Omar Dahbour, 2002). National identity is not a trait with which people are born; rather, experiences from the common lives of people that build their identity. If one views national identity positively, it is typically called patriotism. In pursuance of selfrespect, sense of belonging, sense of security and to afford people some meanings in their lives, national identities are essential. National identity is a creditable form of identification (Nielson Kai, 1999).As a stimulating measure, self categorizationis needed for national identity. This implies identification of an in-group (association with one's nation) as well as discrimination of out-groups (other nations). Realization of similarities like common descent and identical destiny help people in associating with one particular nation to form an in-group and simultaneously treating people from a different nation(s) as out-group(s). A well developed and strong sense of national identity has the power to be a productive and enabling force within the society, providing positive social capital, with benefits such as improved cooperation with others, improved information flows and more effective, better functioning government and other democratic institution (Stephen Aldridge, 2002). On the contrary, a nation is a determinate thing. It is not defined by social 
facts (e.g., kinship) but by the beliefs about what those facts are (i.e.convictions about kinship ties). It is necessarily an ethnically self-defined and politically selfconscious group that is usually influenced by the factors of language, national colors, symbols, history of nation, blood connections, culture, cuisine and music etc.

In case of Azerbaijan, process of national identity formulation is an interesting phenomenon. Structured on the components of geography, history, culture and religion, Azerbaijan enjoys a complex yet multi-layered geopolitical identity. Geographically, it serves as the gateway to Europe. Evident European outlook of Azerbaijan substantiates people's liking for Europe. Azerbaijan acceded to Council of Europe in 2001 but refused to sign association with European Union (EU) in 2014. Nevertheless, EU and UK are the biggest trade partners of Azerbaijan. Historically, it has been a part of Russian Empire and the Soviet Union. Despite the serious ideological differences with Russia, still a sizeable majority of Azerbaijani population is observed conversing in Russian. Furthermore, Azerbaijan became member of Commonwealth of Independent States (CIS) in 1993. Culturally and linguistically, Azerbaijan is a part of the Turkic World. Process of Turkic integration started in 1990s. Later, Cooperation Council of Turkic-Speaking States (CCTS) was formed in Nakhichivan / Azerbaijan in 2009, involving Turkey, Kazakhstan and Kyrgyzstan. From the religious stand point, Azerbaijan is a secular Muslim country that emulates exemplary inter-faith / inter-sect harmony, spirit of peaceful coexistence and multiculturalism. It may look different from many Muslim countries in social, political and economic dispositions but remains to be an active member of Organization of Islamic Countries (OIC) since 1991. Not with standing the above mentioned facts, Government of Azerbaijan is striving hard to foster an independent Azerbaijani national identity that is premised upon secularism, civic nationalism and multiculturalism. Cumulative desired effect of all these efforts is to project a soft image of Azerbaijan in the comity of nations.

\section{National Image}

Image refers to an overall opinion or the total impression an entity makes on the minds of others (Dichter, 1985).It is generally considered to be the sum of people's cognition, affection and evaluation regarding an object, person, or organization. An image is the subjective portrait of a part of reality that is perceived by a person or a group of people. Relevant to scholarship in strategic communication, an image can be a country, an institution or organization, a brand or product, a label, to name a few (Abrudan \& Mucundorfeanu, 2009). 
In the realms of strategic communication, marketing communication or consumer behavior, the country of origin (COO) effect focuses specifically on the association between product and overall national image of the nation, producing that product. A positive country image is positively correlated with perceptions of product integrity, pride of ownership, product satisfaction, willingness to buy from particular countries, and general product knowledge (Papadopoulos, N. and Heslop L, 2002). National image can be seen as the cognitive representation that a person holds of a given country, what a person believes to be true about a nation and its people (Kunczik, Michael 1997). Many researchers agree that impressions / general evaluations of countries by consumers over a period of time tend to serve as buzzwords or judgment shortcuts. Thus, it is the sum total of all descriptive, inferential and informational beliefs one has about a particular country (Ingrid M. Martin and Sevin Eroglu (1993).Consumers with little product knowledge depend more on country of origin (COO) information to assess the product as compared to people having more knowledge related to the same product. Apt projection of product related national image pays rich dividends. It is in this backdrop that scores of developing countries have recently joined the cult of developed nations who are using soft power for image projection.

\section{Product Related National Image}

Before delving into the nation branding practices, it seems prudent to assimilate the impact of product related national image towards global standing of nations. National image or country image has been an important subject discussed in a variety of communication disciplines (Luther, C.A, 2002). Countries are famous globally for different reasons. USA is known for the state of art cyber technology, aircrafts, spacecrafts, optical, technical and medical equipment. China is eminent due to low cost manufacturing capability, connectivity mega projects and abundant provision of Chinese products till the remotest part of the world. UK dominates European Continent as the financial leader with London as the hub of commercial initiatives. Russia and Gulf countries excel in domain of petrochemicals, often leveraging their hydrocarbon riches for deriving politico-economic mileage. Japan is popular for itscutting edge computer technology, automotive industry and electrical appliances. Germany is known for its vehicles, machinery, electrical equipment, medicines and for provision of apt business conditions to world entrepreneurs. In the same context, South Korea is known for its cellular phones and electrical machinery, Switzerland for the banking industry and tourist attractions, Pakistan for textiles, sports goods and edible items, India for cheap human resource and IT potential and South Africa for the diamond industry. 
Prowess of a nation in a peculiar product range also leads to increased exports of the same product from that country. Suits and shoes from Italy, perfumes from France, watches and chocolates from Switzerland, crystal ware from Czechoslovakia, rice, mangoes and textiles from Pakistan and the construction consultants of Turkey, can be cited as examples.

Sometimes a country's name adds credence to the value of the product. Economic turnaround of Japan is a brilliant success story of modern times. There was a time when "Made in Japan" carried a negative connotation for most of the consumers as most Western countries considered Japanese products to be cheap, worthless and second rate commodities. However, with the turn of tide, Japanese products are now labeled as a consequence of most up-to-date technology, highest quality, style prowess and competitive pricing. Images of countries only ever change for two reasons: either because the country changes or because it does something to its people (Anholt, Simon, 2007)The countries which have developed strong and recognized associations of trust, quality and integrity on the global front, the manufacturers of such countries always enjoy the perks of being associated to those. In a globalized world, such an affinity is an added advantage. This edge is akin to a product being tagged to its parent brand. The increased trial that it experiences just because of the parent brand name support puts it way ahead in relation to a new product with no prior associations.

It is a matter of common observation that cola remains synonymous to USA, pizza to Italy, perfumeries to France, wines to Georgia, skis from Slovenia, dairy products from Australia and New Zealand and vodka from Russia. People might buy Indian accountancy software, Pakistani fabric or Swiss watches but may not be comfortable in purchasing Indian wine, Turkish mobiles or Iranian computers. Having said this, it might not always be true because if there is anything more permanent or constant in marketing, that is 'change.' Attitudes can and do change very quickly (Anholt, Simon, 2007). Consumer behavior predictions have more often proved to be more wrong than right. The success of marketing efforts often occurs as a consequence of an obstinate and resilient marketer, who does not rely solely on the findings of consumer research. One needs to understand that nations have to continually strive for favorable attention of the audience; as once this battle is won, political advantage and economic dividends are achieved.

Governments of states try to use popular brands for furthering nations' image worldwide. Leverage for a brand to evolve at its own, is somewhat limiting due to this growing influence. It is no longer a question of 'to brand or not to brand' for a state's government, but rather a decision of doing the branding or going bust (Van Ham, 2002).It is the buyers, not the sellers 'opinion which matters. In other words, 
a country should be selling what the 'buyers' - that is, tourists and consumers abroad- are interested in paying for, rather than what a ' seller'- that is, a country, its politicians and population at large - decides to offer or sell. Ad hoc brand campaigns rarely if ever bring expected 'dividends'. To be effective, imageformation not only needs to be constantly managed, but also needs to rely on timetested marketing techniques. (Ausra Park, 2008).

\section{Nation Brand and Its Personality}

A nation brand is any attribute associated with a country that affects the brand image of the country. Although there is some contentiousness over treating a country as a brand, evidence shows that employing business branding strategies can significantly enhance a country's brand image (Klein, J. G. (2002). The enhancement of a nation's image benefits many countries outside their borders for the export of products and on their own soil attracting tourists from other countries (Kleppe, I. A., Iversen, N. M., \&Stensaker, I. G, 2002). Process of branding a country is somewhat akin to branding a business. Either implemented by marketing / advertising staff of a company or by the responsible government officials to communicate views on governance and commerce, almost similar techniques can be utilized for image projection. In both the cases, overarching belief remains the same, which states that people can be influenced in similar ways. A healthy brand is beneficial for a country in many ways. For example, tourism or destination branding (Caldwell, N., \& Freire, J. R, 2004) is greatly augmented by healthy nation brands. Despite being the brands themselves, nation brands offer extrinsic clues about the product evaluations.

Nations can be viewed as brands that encompass multiple dimensions in their role as producers, exporters, investment locations and migration or tourism destinations (Rojas-Méndez, J, 2013).However, the extant differences between a nation and the brand need to be carefully studied. By no means can a nation be termed as a product. Similarly, a nation brand suggests no tangible product or service. It rather exhibits a wide range of affiliations, place, natural resources, people, history, language, social institutions, political and economic systems, icons and images.Dissimilar to products or the services, people may hold pre conceived notions or buzzwords about a nation, as it can conveniently be linked to their values or cultural beliefs. This argument turns the nation brand personality into a sort of nation stereotypes. 


\section{Nation Branding in Practice}

Nation branding is a process by which nation's images can be created or altered, monitored, evaluated and proactively managed in order to enhance the country's reputation among a target audience (Fang, T, 2010). Out of these tiers, nation image management is the most crucial one since it assists in overcoming people's disbelief about the use of nation branding. Simultaneously it clarifies what can be branded and what cannot. To advance nation image management, it seems important to as certain how country image is constructed and how does it associates with the product evaluation. By employing soft power tools intelligently, projection of national brands can heighten the national identity. Nation branding comprises many levels that include national identity, national image, nation's soft power, nation's competitiveness, umbrella brands and management of visual symbols (Fan, Y, 2008). Despite varied implications of principles and practice of nation branding, the embedding of national identity in brand campaigns enriches consumers' understanding as national citizens and global subjects. Nation branding is the art of applying the branding and marketing communication techniques to promote nation's image (Ying Fan, 2006).Nation branding complements citizens' commitment to the terms of political self-determination and ideals of public communication.

Arguably, one of the main goals of public diplomacy is to cultivate and communicate a certain image or reputation of a nation state to the international audience. Same is true for nation branding as well. Nation branding represents the desire of concerned states to persuade people in paying attention towards their particular nation state, its achievements and belief in its qualities. Theoretical consensus on nation branding is a rarity; authors such as (Simon Anholt, 2007) believe that nation branding is an indispensable phenomenon in the globalized world. Anholt further argues that nations must compete for visibility in an increasingly crowded and globalized environment. His critics like Aronczyk however, opine that nation branding is a version of soft nationalism and remains a process that governments continue to buy into (Aronczyk, Melissa, 2009).Whilst nation branding is an internationally focused phenomenon, it is a practice that retains the capacity to illuminate the more salient narratives of nation building and, in some cases, reflects nationalist rhetoric of politicians (Paul Jordan, 2014). A country needs to make itself known amongst the nations, if it wishes to prove its reliability and credence. Nation branding does the trickby stimulating investment inflows, attracting tourists and boosting the exports (Anholt, Simon, 2007).Unlike products, nations are complex entities and nation branding at times strips them down to an extremely simplified object to improve the marketability of a state. Critics raise queries on viability and desirability of branding something as 
complicated as national identity, which at the same time can be used as a tool for doctoring histories, memories and rituals, which under pin and encapsulate the nation (Jordan, Paul, 2014).

\section{Azerbaijan - The Land of Fire}

Azerbaijan is a stable and safe Muslim country of South Caucasian region, which is blessed with a fast developing economy, sizeable hydrocarbon riches and distinct geo-strategic location. It lies at the crossroads of Southwest Asia and Southeast Europe. A balanced interplay of geo-strategic location and available energy resources makes Azerbaijan a key player in the regional and global matrix. Esthetic traces of Ottoman, Russian and Prussian Empires transform Azerbaijan's historical and cultural legacy into a highly affluent heritage. It is a secular country witha pluralistic society enriched with commendable spirit of co-existence. Safe and secure domestic environment coupled with stable political dispensation makes Azerbaijan an island of peace in middle of a burning region.Country's economy is heavily contingent upon the oil revenues. Current regime is however, trying to diversify the economy in non-oil sectors. While appreciable fiscal space and peaceful domestic environment helps in attracting foreign direct investment, mesmerizing beauty and traditional hospitality shape Azerbaijan into an ideal tourist destination. With help of persuasive nation branding initiatives, efforts are being done to internationally project the 'Brand Azerbaijan'.Broad based fiscal reforms, economy diversification efforts, liberalization of trade regime, simplified visa procedures and state patronage of indigenous industrial production work in tandem with nation branding effort of Azerbaijan.

Azerbaijan follows a relatively independent foreign policy with no major favorites. At times, this act of balancing the regional obligations with global compulsions becomes walking on a tight rope. Azerbaijan however, exercises a careful balance in its relations with global, regional and Islamic powers. It continues to maintain good relations with Russia and USA, Iran and Israel, India and Pakistan, Turkey and Europe, China, Trans Caspian Central Asian States and other countries of Muslim Ummah. Unresolved conflict of Nagorno Karabakh and liberation of 20\% Azeri lands from Armenian occupation are the corner stones of foreign and defence policy of Azerbaijan. Year 2016 was celebrated as Year of Multi-Culturism (http://www.azernews.az/nation/91533.html), and year 2017 has been declared as Year of Islamic Solidarity (http://en.president.az/articles/23020). Exploiting its geo-strategic location, Azerbaijan provides a safe conduit for transportation of energy riches from Caspian Sea to Europe, without having to pass through Russia 
or Iran. This geographical aspect helps European Union (EU) in improving the diversity and security of Energy supply from its East. Taken into account terrestrial proximity, cultural heritage, historical and ethnic linkages, regional integration, human rights conditions, legal / administrative traditions and gender equality, Azerbaijan stands out to be more Eurasian than its Central Asian neighbors.

At the economic front, Azerbaijan has made larger strides from signing the 'Contract of the Century' (http://en.president.az/azerbaijan/contract)in 1994 to the inauguration of 'Southern Gas Corridor'(http://www.bp.com/en_az/caspian/ operationsprojects /Shahdeniz/SouthernCorridor) project in 2014. Like all oil producing countries, Azerbaijan remains vulnerable to 'Oil Curse or Dutch Disease'. Due to heavy reliance on petro dollars, only oil industry stay in focus and other industries are grossly neglected. Consequently, non-oil sector growth does not correspond with petrochemical industry. In a period of low oil prices, such a non-diversified economy gets roughly exposed. To offset this disadvantage, recently Azeri Government has started focusing ongrowth of non-oil sectors. Initiation of broad based economic reforms, abolition of monopolized trade regime and increased emphasis on socio economic development some worth mentioning measures. Government seems committed towards macroeconomic stability besides controlling inflation / unemployment. According to President Ilham Aliyev's speech at Davos during World Economic Forum-2016, "Azeri economy is maintaining healthy growth rate. Over the past 10 years, country's economy has grown by $300 \%$. Poverty and unemployment have reduced sharply, currently staying at $5 \%$ each. Growth of non-oil industry sector is at $8.4 \%$.Azerbaijan has been ranked as 40th in the world for competitiveness and the first in the CIS region during 2016 by the World Economic Forum". An export-oriented economic model equipped with modernization of oil and gas industry, diversification of non-oil sectors, expanded use of renewable energy resources, development of agrarian sector, strengthening of food security, boosting up of trade and services and composite measures to enhance foreign direct investment are elucidated as the priority areas of ruling regime.

\section{Rationale of Nation Branding For Azerbaijan}

Generally, the perception of Azerbaijan weakens as one geographically distance away from it. Western Europe and USA have the least understanding of Azerbaijan as compared to Russia, Turkey, Iran or Georgia. To solicit global recognition, Azerbaijan has embarked upon an ambitious journey to prove international 
credentials and improve its global acceptability. A conscious effort has been undertaken to project Azerbaijan as an economic trailblazer in Common Wealth of Independent States (CIS) region. György Szondi, 2008 argues that nation branding can help transitional states to distance themselves from the previous political system (Communist Rule in the Azerbaijani context), as well as help to portray the country as a modern state and eligible member of a new world system, positioning the country as a central rather than peripheral state.

Due to available scope and ever growing awareness about the nation branding, Azerbaijan offers the best model in the form of a secular, tolerant, forward looking and economically prosperous Muslim nation that has regional as well as global aspirations. In a bid to keep Azerbaijan perpetually blinking on foreign policy radars of regional, European and Islamic countries, mega events of international stature are hosted at Baku with regular intervals. The frequency has particularly increased during last five years. Eurovision International Song Contest-2012, $1^{\text {st }} \&$ $2^{\text {nd }}$ Azerbaijan Defence Exhibitions (ADEX) in 2014 \& 2016 respectively; Inaugural European Games-2015, International Chess Olympiad-2016, European Grand Prix Formula One Racing Round-2016, and $7^{\text {th }}$ Forum of United Nations Alliance of Civilization Forum (UNAOC) - 2016 can be cited as examples. In 2017, Azerbaijan plans to host $2^{\text {nd }}$ Round of European Grand Prix Formula One Racing \& $4^{\text {th }}$ Islamic Solidarity Games. Surge in tourism experienced during 2016 and 2017 can partly be attributed to the befitting conduct of above mentioned mega events. In pursuance of its nation branding objective, Government of Azerbaijan has launched number of initiatives like "Amazing Azerbaijan", "Azerbaijan-The Land of Fire" and "Made in Azerbaijan" etc. Endowed with mesmerizing natural beauty, blessed with a vibrant economy and supported by coherent Governmental efforts, Azerbaijan is being successfully promoted as a brand across the globe. Government aspires to support 'Brand Azerbaijan' initiatives through generous funding and state patronage.

\section{National Brands of Azerbaijan}

As discussed earlier, Azerbaijan does not have high international visibility, despite advantages of geography, economy, secure domestic milieu and political stability. Azeri Government therefore, has embarked upon a well meditated nation branding campaign to create a distinct national image of post-Soviet state. It also serves to highlight uniquehistory, culture, folklore, traditions, social / moral values, natural beauty and human capital of Azerbaijan to the remaining world. 
Unfortunately, however, Azerbaijan has very little brands of its own at the moment. Non availability of enough national brands is an impediment to nation branding aspirations of Azerbaijan. With ongoing economic reforms and diversification of economy, it is hoped that situation will get better soon. In case thelocal industry is developed futuristically, it will enable Azerbaijan to produce the items that have a competitive edge in quality over the rivals. Apt nation branding efforts may project the obtaining qualitative edge in regional or global markets and heighten the Azerbaijani identity in consequence. Currently, Azerbaijan is knownfor its tea, pomegranates, apples, carpets, wine, silk scarfs, Mugam music, traditional dresses, customary jewelry and achievements in sports particularly athletics. The tiny nation ranked $39^{\text {th }}$ in Summer Olympics 2016 and secured a total of $16 \mathrm{x}$ medals. Orderly conduct of mega events of international stature is also a trademark of Azerbaijan.

State Oil Company of Azerbaijan Republic (SOCAR) is one of the top Azeri brands, whose expertise in the petrochemical domain remains laudable. SOCAR is carrying Azerbaijani flag to the region and beyond with commitment and pride. This state oil giant is attempting to promote Azerbaijani image in Turkey, Georgia, Russia, Central Asia and even UK in a praise worthy manner. "SOCAR intends becoming the largest foreign investor in Turkey with an investment volume worth $\$ 17$ billion by 2018 (http://www.usacc.org/news-a-publications/investmentnews/688-socar-announces-plans-to-invest-in-turkey.html).Another example is of Hyder Aliyev Foundation, which holds cultural events internationally to promote Azeri image. Its contributions in philanthropist and social welfare domains help in casting a noble impression, well beyond Azeri frontiers. Asan Khidmet (ASAN) is yet another signature brand of Azerbaijan that provides superior quality and uniform communal services. Nine ministries simultaneously work under the same roof to afford one window facility to all Azeri citizens. National flag carrier Azerbaijan Airlines (AZAL) is another proud national brand of Azerbaijan. In the private sector, mega entrepreneurs like the Pasha Group, Gilan Group and Azersun are contributing positively for promotion of Azerbaijani brands, both inland and abroad. Of late, tourism has emerged as a booming industry / distinction of Azerbaijan. Picturesque landscapes of north eastern regions of Azerbaijan and capital city Baku (also known as the City of Winds) generate healthy prospects for the destination branding. 


\section{‘Made in Azerbaijan' Campaign}

The recently initiated "Made in Azerbaijan" campaign is a Government-backed project, which ushers an expedition towards indigenization and self-reliance. It is a conscious attempt to convey a certain narrative of Azerbaijan to international community and ensures good perception management. In a way, nation branding is being used as a tool for projecting soft nationalism. As the nation's hierarchy realizes the significance of soft image projection, its earnest urge to promote national brands, gaining global recognition and attracting foreign direct investment remains evident. Projecting Azerbaijan's business interests internationally, the initiative is aimed to achieve greater direct foreign investment, expand the tourist base and broaden the scope of Azerbaijan's exports to the world markets. Such initiatives reflect a kindlier face of Azerbaijan's nationalism to a global audience. Posters featuring the "Welcome to Azerbaijan - The Land of Fire" logo and "Discover Azerbaijan", "Lights out, Formula One Finally Races in Baku", "Made in Azerbaijan" appear on billboards abroad and at the national airports, quite often.

\section{Conclusion}

Gleaning from above, it is established that using soft power tools intelligently, nation branding can help in projecting the desired national image of a nation. Such endeavors not only project a country's soft image but foster a deeper sense of nationalism amongst its masses, both inland and abroad. Nation branding also help in achieving greater direct foreign investment, expanding tourist base and broadening the scope of exports to world markets. Nation branding in practice is no more the exclusivity of developed nations alone as the developing and under developed nations are equally trying to build and manage their desired soft images. Azerbaijan is a fast developing Muslim nation of South Caucasus region, which has joined the bandwagon and embarked upon a journey to improve its international credentials. Cogent efforts are being put in to project soft image of Azerbaijan as a tolerant and multicultural society, which is an economic trailblazer in Eurasian region. The recently initiated "Made in Azerbaijan" campaign manifests Azeri desire for global recognition. It is an attempt to reflect a kindlier face of Azeri nationalism to the global audience. 'Made in Azerbaijan' helps in projecting soft nationalism, within and outside the country. 


\section{References and notes:}

Anholt, Simon. "Competitive Identity" 2007. 10.

Anholt, S. "Brand New Justice: How Branding Places and Products Can Help the Developing World. Amsterdam: Elsevier Butterworth Heinemann." 2005.

Aronczyk, Melissa. "How to Do Things with Brands: Uses of National Identity Canadian Journal of Communication", Vol 34. 2009. 291-296.

Alpaslan Danisman, S. and Kocabacak , A . What is The Envisioned Future of Azerbaijan Companies? The Case of Chamber of Commerce and Industry. Khazar Journal of Humanities and Social Sciences.Volume 17, Number 4. Khazar University Press, Azerbaijan. 2014. p.29-42

Caldwell, N., \& Freire, J. R. The differences between branding a country, a region and a city: Applying the Brand Box Model. Journal of Brand Management, 12(1), 2004. 50-61.

Fang, T. Asian management research needs more self-confidence: Reflection on hofstede (2007) and beyond. Asia Pacific Journal of Management, 27(1), 2010. 155-170.

Fan, Ying. "Branding the Nation - What is being branded? Journal of Vacation Marketing, 2006. 12:1, 5-14.

Fan, Y. Soft power: Power of attraction or confusion? Place Branding and Public Diplomacy, 4(2), 2008. 147-158.

György Szondi. Public Diplomacy and Nation Branding: Conceptual Similarities and Differences, November 2008. pp. 42.

Klein, J. G. Us versus them, or us versus everyone? Delineating consumer aversion to foreign goods. Journal of International Business Studies, 33(2), 2002. 345-363.

Kleppe, I. A., Iversen, N. M., \&Stensaker, I. G. Country images in marketing strategies: Conceptual issues and an empirical Asian illustration. Journal of Brand Management, 10(1), (2002). 61.

Jordan, Paul. "Nation Branding: A Tool for Nationalism?" Journal of Baltic Studies. Vol. 45, No. 3, September 2014. 283-303.

Park, Ausra. 'Selling 'a small state to the world: Lithuania's struggle in building its national image, Place Branding and Public Diplomacy" November 2008. 67-84.

Rojas-Méndez, J. The nation brand molecule. The Journal of Product and Brand Management, 22(7), 2013. 462-472.

Van Ham, Maarten. "Job access, workplace mobility and occupational achievement." 2002.

"Speech at 13th Summit of Economic Cooperation Organization (ECO)" http://en.president.az/articles/23020 -

"Contract of the Century" http://en.president.az/azerbaijan/contract -

http://www.bp.com/en_az/caspian/operationsprojects/Shahdeniz/SouthernCorridor.html

Dutch disease is the apparent causal relationship between the increase in the economic development of a specific sector (for example natural resources) and a decline in other sectors (like the manufacturing sector or agriculture).

http://www.usacc.org/news-a-publications/investment-news/688-socar-announces-plans-toinvest-in-turkey.html 
https://madeinazerbaijan.com/ 


\title{
Summary
}

\section{Reshaping the National Image of Azerbaijan through Nation Branding Endeavours}

\author{
Sana Imran \\ Khazar University, Azerbaijan
}

Every nation possesses a nation brand image, either with or without nation branding. A well thought out nation branding campaign can however, project a nation's image and solicit global recognition. Such an endeavor concurrently instills a greater sense of belonging, self-determination and ideals of public communication in the domestic audience. The value of nation branding for tapping the economic potential of a nation remains arguable. In this paper, an effort is being made to understand how a developing country like Azerbaijan is accruing international recognition through apt utilization of nation branding tools. Strategic, conceptual and practically relevant aspects will be analyzed to ascertain efficacy of nation branding techniques and their impact on national image building. With occasional reference to the international brands of developed countries, focus will remain on endeavors of Azerbaijan to market its name and build own national brands.

Key Words: Nation Branding, National Identity, Nationalism, Global Recognition, Brand Azerbaijan. 